\title{
DELIVERY CHALLENGES AT A MECHANICAL TESTING CENTRE FACILITY: A CASE STUDY OF A RAILWAY SYSTEM IN SOUTH AFRICA
}

\author{
F. Masithulela ${ }^{1 *} \&$ K. Ramdass ${ }^{2}$ \\ Department of Mechanical and Industrial Engineering, South Africa \\ College of Science, Engineering and Technology \\ University of South Africa \\ 1'masitfj@unisa.ac.za, 2ramdakr@unisa.ac.za
}

\begin{abstract}
The Mechanical Testing Facility, which is a division within TT Pty (Ltd), provides component mechanical testing to other divisions tasked with implementing new components in the railway system. The records over seven years show a steady increase in the number of tests delivered late to clients. In this paper, the background to the facility is provided, which extensively details the processes and relationships between the resources involved in the process. An analysis of the root causes for the late delivery of tests shows that lack of training and ineffective management were among the most significant reasons for late delivery. Recommendations for improvement include more active accountability of all resources, enforcement of standard operating procedures, and technical training for each resource specific to their tasks. Quick wins identified to drive these improvements included the implementation of key performance indicators for each resource, improvement of storage methodologies, and agreement of standard service levels with partners.
\end{abstract}

\section{OPSOMMING}

Die Meganiese Toetsfasiliteit van TT Edms (Bpk) verskaf meganiese onderdeel-toetsing vir verskeie afdelings binne die maatskappy. Hierdie afdeling het die ontwikkeling van nuwe onderdele vir die spoorweë as doelstelling. 'n Geleidelike toename in die aantal toetse wat laat afgelewer is, is oor die afgelope sewe jaar waargeneem. In die artikel word die agtergrond tot die fasiliteit verskaf waarin die prosesse en verhoudinge tussen die betrokke hulpbronne in detail beskryf word. ' $n$ Analise van die kern oorsake vir die laat aflewering van toetsresultate toon dat ' $n$ tekort aan opleiding en ondoeltreffende bestuur die hoof oorsake is. Aanbevelings vir verbetering sluit meer aktiewe aanspreeklikheid van al die hulpbronne, die toepassing van standaard operasionele prosedures en die tegniese opleiding van elke hulpbron spesifiek tot hul opdrag, in. Vinnige winste wat geïdentifiseer is om hierdie verbeteringe te dryf sluit die implementeer van sleutel prestasie-aanwysers vir elke hulpbron, die verbetering van stoormetodieke en die ooreenstemming van standaard diensvlakke met vennote, in.

Corresponding author 
The material testing system (MTS) was established in 1997 with the sole purpose of providing component testing and quality assurance for all new components used in the rail system. Most of MTS' clients are also divisions within the TransLogic freight rail department TFRD, including the Bogies Technology, the Couplers and Draw Gear, the Wheel/Rail Interaction, Brakes Systems, Wagon Design, Overhead Power Supply, and Electrical Infrastructure. The Ishikawa diagram and SWOT analysis are tools used in solving challenges at the mechanical testing centre.

Although each of the divisions is able to approach external vendors for such services, the MTS provides more favourable pricing and is an accredited testing centre. On occasion, the MTS also receives orders for performing tests on specimens from other large industrial companies. The MTS has a very high staff turnover, which began in 2004 with the resignation of the previous operations manager, followed by the resignation of the engineering technician in 2005. Reasons cited for leaving were mostly financial in nature, as well as better work opportunities. The engineer, although relatively junior, is the next highest rank below the operations manager; he is responsible for coordinating the day-today activities of the facility, given that the operations manager also manages the Mechanical Projects, Vehicle Dynamics, and the Rolling Stock Test and Development Centre RSTDC.

\section{LITERATURE REVIEW}

Quality in the railway industry is becoming paramount due to various factors, such as competition, global trends, traffic in road freight, client demands, and so forth. Quality is used as a competitive weapon that, if applied correctly, enhances business performance and efficiency [1-3]. Product and service quality ultimately determine client satisfaction. Quality in an industry that deals with human lives on a daily basis needs to be free of technical failures, human errors, and any type of imperfections. With complex technical and technological systems, managers are held accountable for the performance of the finished product. Testing of railroad parts is basic for the general population's wellbeing. Safety and wellbeing in railroads can be characterised as the capacity of a rail line mechanical framework to reduce dangers to the life and soundness of individuals (e.g., travellers, nearby populace, and operational staff), material damage, and a risk to the natural parity of the earth because of the impact of goal or subjective, interior or outer destabilising variables influencing the framework [4-7]. Occurring accidents are a measure of safety.

In order to assess the situation and improve its competitiveness, railway transport as a whole should implement urgent measures. Thus, there is a need to look at how mechanical testing is done. For example, the testing must be performed according to regulations. The correct understanding and evaluation of the nature of service quality and its properties is the most accurate way to identify shortcomings and improve the service quality and competitiveness thereof. Such a system depends on learning administration with respect to all undesirable and unintended occasions, conditions, and procedures that effect adversely on some part of administration quality. Although all properties of quality are important and should mandatorily be analysed, safety is the key issue (transport services should primarily be safe) within the overall knowledge management system. In other words, a safety management system of a given railway undertaking (supported by an organisational knowledge management system) is a major part of its quality management system. The nature, main components, and features of such a system are discussed in this article.

The delivery of quality service in time is critical to the survival of any business today. Most clients insist that they receive their services within the agreed time frame. If this does not happen, the business success rate or ability begins to suffer and eventually dies [8]. This paper introduces a general framework to model a large collection of pickup and delivery problems, as well as a three-field classification scheme for these problems. It surveys the 
methods used for solving them [8-10]. The delivery of services in time or as per the agreed schedule is a problem in all spheres of our lives [11-13]. Travelling problems have been discussed by Rosenkrantz et al. [10], while Ala-Risku and Kãrkkãinen [14] discussed the material delivery challenges for the construction industry. In their study, a possible solution for the delivery process of materials during emerging project management methods was developed [14]. Ala-Risku and Kãrkkãinen [14] reasoned that the test of furnishing the last organiser with materials accessibility data is because of site stock control systems. Every now and again, the materials on location are not enrolled legitimately in any stock control framework, and along these lines, should be outwardly controlled to guarantee that they are accessible [15]. At times, site inventories are observed with a spreadsheet application. Manual processes tend to flaw the process and cause the inconsistent registering of the material movement in the process [16]. Therefore, the manual process is not desirable as it increases the work load of the planner. As a result, more effective means for creating visibility to site inventories are needed [17-19]. Poor facility layout, which could lead to a bottleneck in the process, is also argued to contribute enormously to the poor performance of the facilities [20-23].

\section{FACILITY BACKGROUND}

In this section, a detailed background of the facility is provided with the organisational structure as a holistic overview of the MTS. This would enable the provision of the context of the study in question.

\subsection{Facilities}

The facility's load frames are limited in component size and cannot accommodate complete wagons. The lifting capability of the overhead crane is limited to five tons. It is for these reasons that the facility cannot perform tests on complete wagons. Wagons are tested in other competing facilities within the group. The facility also has a mobile crane with a capacity of two tons. The facility has a total of eight actuators, which can be used individually or in a test group. The number of and manner in which actuators can be grouped are limited by the electronic controllers, as well as by physical constraints. Cross anchors are used in MK IV bogie type to assist in curving performance. The servo-hydraulic equipment has limitations, such as the amount of force that can be applied by each actuator, the frequency of load application, and the displacement of each actuator. All the divisions are situated in close proximity to the Material Testing System (MTS) facilities.

\subsection{The organisational structure}

The MTS operations manager has been with the division for two years and has been with TFRD for seven years. Four employees are permanently assigned to the facility: the engineer, technical supervisor, engineering technician, and the workshop assistant. Cleaning services are provided by a contracted company. The organogram for the MTS is provided in Figure 1.

The longest-serving employees in the department are the technical supervisor and the workshop assistant who reports to him. Both have been with the MDS for more than ten years. The technical supervisor currently reports to the engineer who has been at the department for a year. The engineering technician is at the same level as the technical supervisor and has been working at the MTS for one year.

\subsection{Test request procedure}

Although the formal test request procedure requires that test requests are routed to the engineer, test requests are often received by any of the MTS representatives; i.e., the operations manager, the engineer, or the technical supervisor receive requests verbally or via email from an engineer in charge of testing within client organisations. On receipt of the request, a test request form is forwarded to the client for completion. The client 


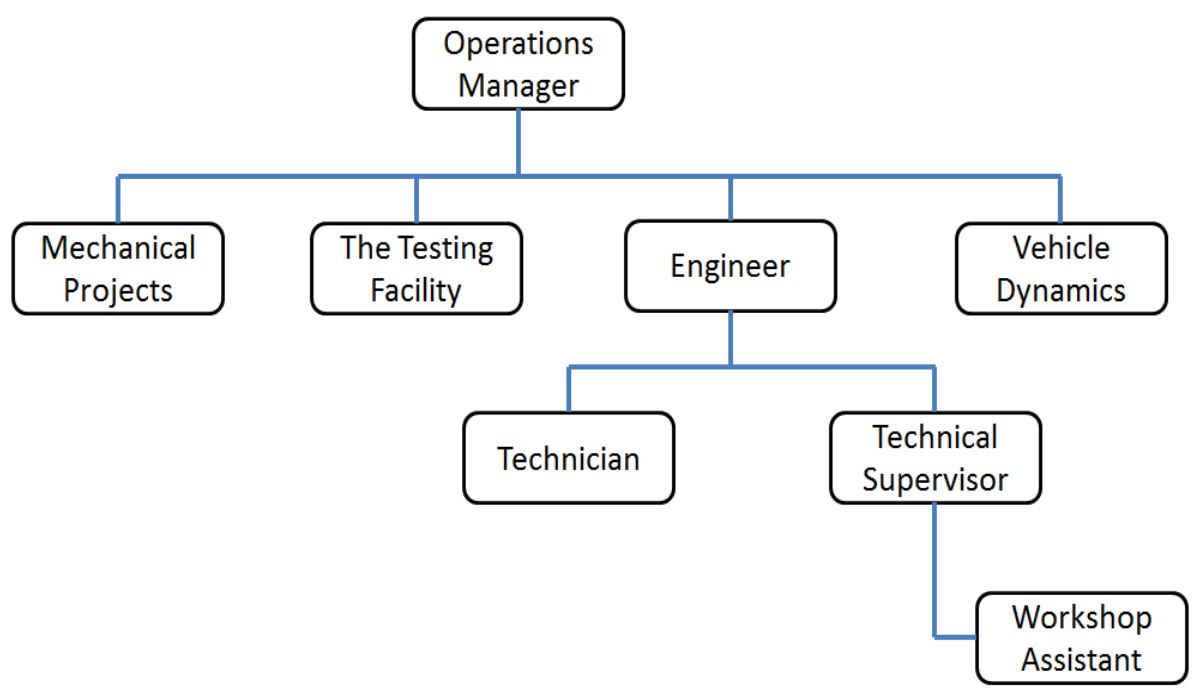

Figure 1: MTS's organogram

returns the completed form to the MTS representative, who is then able to make an assessment of the test requirements.

On the form, the client is required to provide a number of key information items. The client must specify whether the jig to be used for the test will be provided, retrieved from MTS storage from previous tests, or designed specifically for the test. In addition, the client must specify whether instrumentation of the specimen is expected to be performed by the client or by the MTS. The client indicates if the MTS data acquisition equipment will be used for recording; the MTS has data acquisition capabilities for 32 differential channels, and data can be recorded at frequencies up to $333 \mathrm{kHz}$. Otherwise, the client provides their own data acquisition.

Any queries by the MDS are clarified telephonically or by email, but if this is inadequate, a meeting is arranged between the MDS representative and the client; these meetings are often attended by the operations manager.

After all the information has been obtained from the client in writing, the MTS representative provides the soonest available fixed test date booking and test duration in writing to the client. This estimation is based on past MDS experience in similar tests. In addition, the following dates are documented and agreed on with the client:

- The date that the test specimens must be delivered and made available at the facility.

- The date that the instrumentation of the test specimen must be commenced with at the MDS.

- The date that the specimen test set-up will be performed.

- The date the first preliminary test (shakedown) will be performed.

- The date of commencement for each test series.

- The duration of each test series.

The client is then required to accept these test dates in writing. In the event of a dispute with the proposed test dates, the operations manager negotiates the dates with the line management on the client's side. Clients are charged per hour, based on the time taken to perform the test as agreed on the form. No adjustments are made to the dates after an agreement. In addition, no extra charges are levied on the client for any delays, regardless of the delay reason. 
For each test, the client is also required to provide a test specification, which details the following:

- Description of the physical test setup.

- Description of the manner in which the load should be applied to the specimen. This includes the actuator application positioning as well as the load and/or displacement profiles that are required.

- Instrumentation required per test; e.g., strain gauging locations, displacement, and/or force measurements.

- Number of test cycles per test.

- Specifications on when measurements or data recordings must be taken; e.g., every 10,000 cycles or continuously.

- Necessary calculations for the test to be conducted.

- Intervals at which visual inspections of the specimen should be performed.

- $\quad$ Any safety considerations that MTS staff should be aware of.

- What emergency action should be taken in the event of a crack/deformation by the MTS staff, should the client not be available.

If a test specification is not available, the test request is delayed. All test specifications must be written and approved by the Very Important Technology (VIT) department, within the client business unit. In order for a test to commence, the test request form must be signed by the client and approved by the operations manager.

\subsection{Specimen set-up jigs}

Used jigs are stored within the MTS facility; where the form indicates the use of an existing jig, the jig is expected to be available in storage. The search for jigs is the responsibility of the technical supervisor. If the form specifies that a new jig is required for the test, the client is required to design a jig. The jig is normally manufactured within the in-house machine shop and only outsourced to external vendors where the urgency requires it, at a considerably higher cost to the client. The client is responsible for sourcing the jig manufacturing materials and delivering these to the machine shop. Where in-house manufacturing is used, construction is supervised by the client. The speed of completion of jig manufacturing is dependent on the time taken to find the correct jig setup materials within the workshop, as well as the amount of work already scheduled in the machine shop. All jigs ultimately belong to the client, but can be stored at the MTS when requested by the client.

\subsection{Instrumentation}

Each specimen is required to be instrumented for each test; this is usually conducted in parallel with jig design and manufacturing. Instrumentation often involves a specialised welding method, where the MTS is often assisted by the RSTDC. In the event that this is not possible, the client is requested to make further arrangements with an external vendor. Correct instrumentation is critical to the success of the test, such that if the incorrect instruments are used, or the instruments are attached incorrectly, incorrect results will be reported, and the test must be reinitiated. Only when instrumentation is complete and the test jig is available, can testing begin.

\section{TESTING}

Test setup, which is conducted by the technical supervisor and the workshop assistant, involves physically setting up the test specimens and the instruments. Testing is conducted using a Material Testing System (MTS), which automatically runs all pre-programmed tests. The engineering technician is provided with all the test documentation and he/she conducts the pre-testing procedures; these involve configuring the application for the test, ensuring that the test is completed, and forwarding the results of each test to the engineer. 
On receipt of the results, the engineer processes the results and issues the test certificate, as well as the test report for the client, where required. Both the test certificate and the report are forwarded to the operations manager, who forwards them to the client. This process is illustrated in Figure 2, and the information flow within the process is detailed in Figure 3.

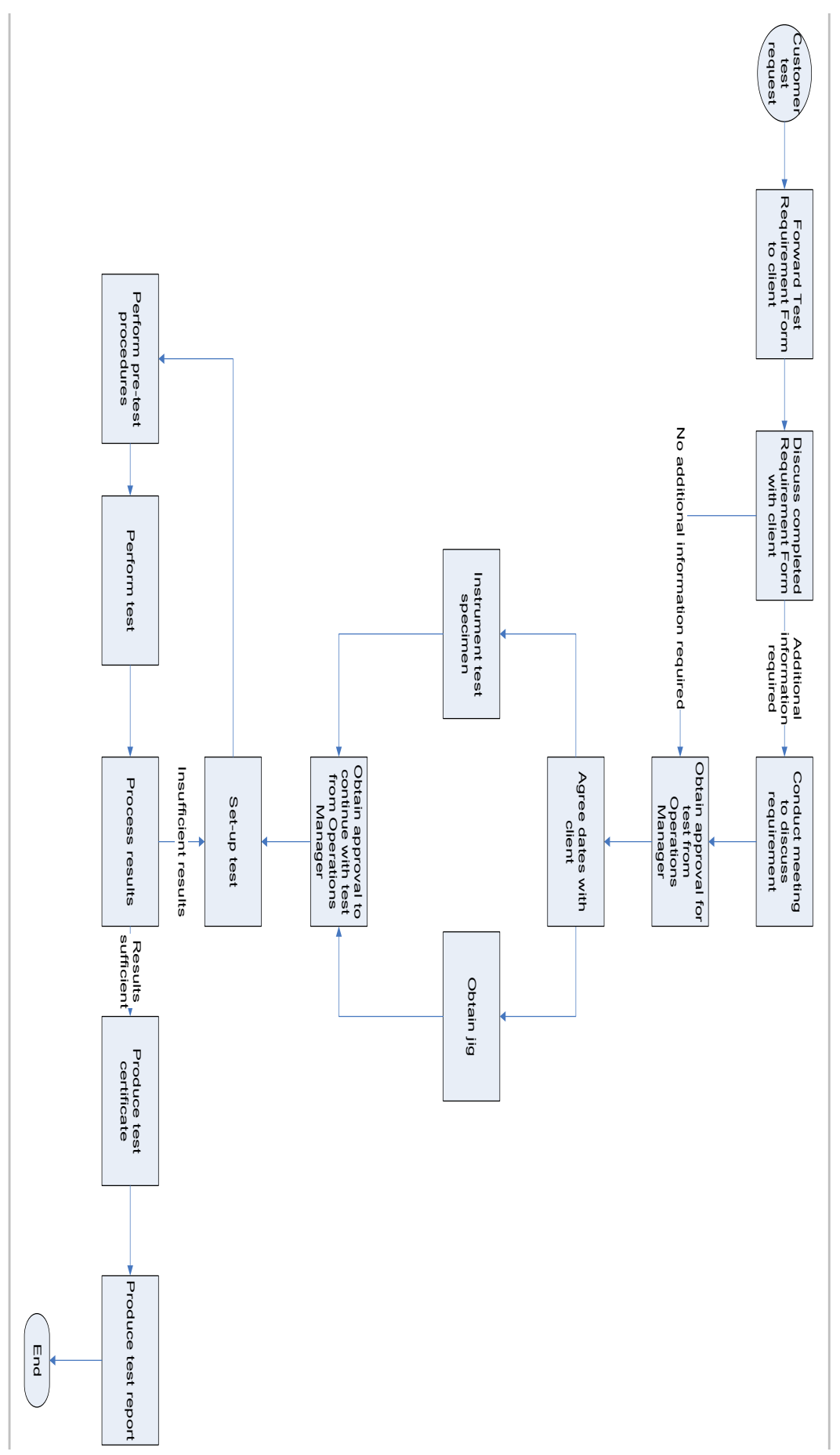

Figure 2: Process flow diagram 


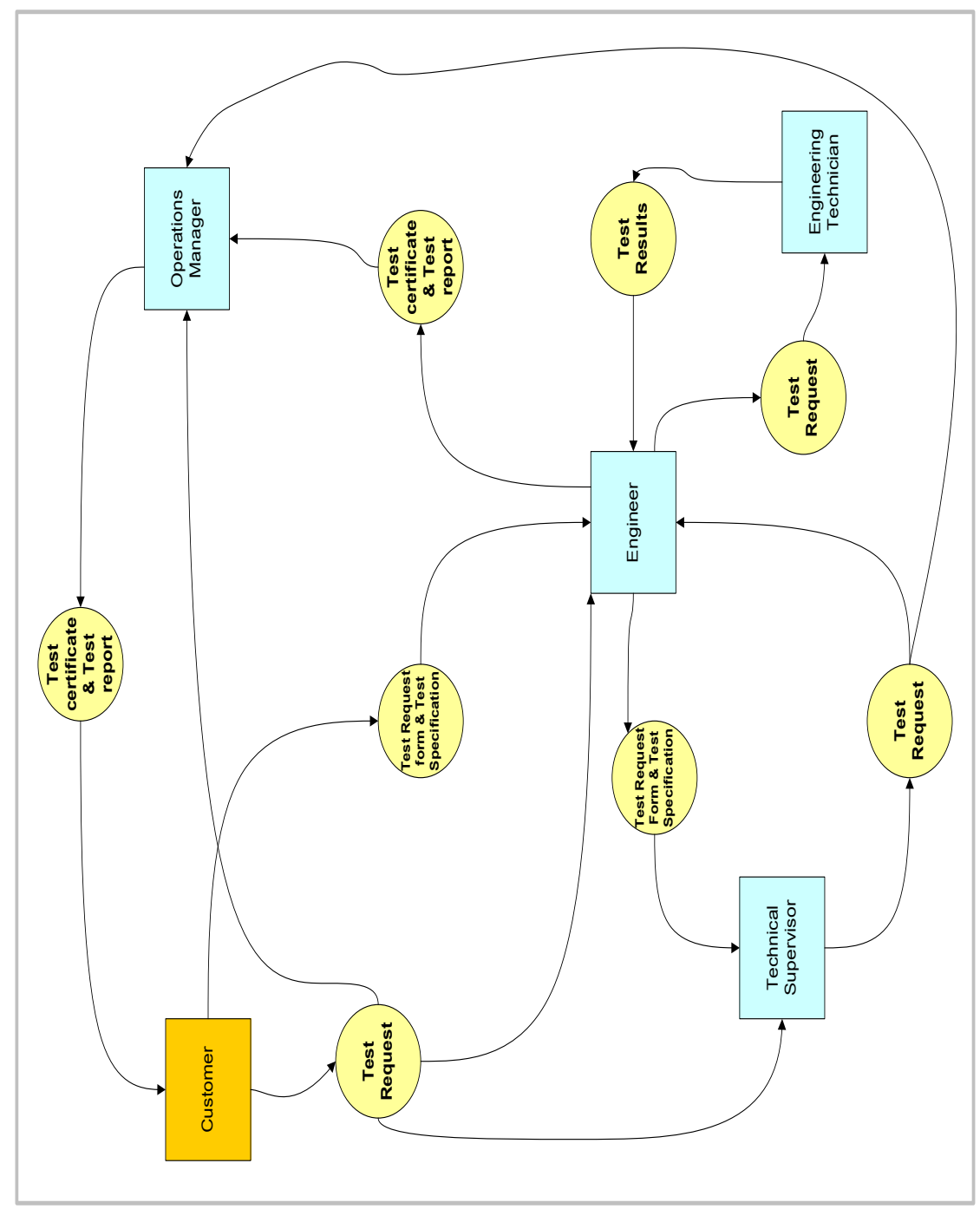

Figure 3: Information flow diagram

\section{Current situation}

While MTS has in the past enjoyed a good reputation of service within TranLogic Freight Rail (TFR), this reputation has been tarnished more recently due to late testing delivery. Although the planned test duration provided to the client initially takes into account various risk factors, such as late delivery of test specimens, faulty test instrumentation, equipment maintenance, test setup, and test breakdown times, there have been several instances where the actual delays experienced have resulted in deliveries much later than the estimated date.

The reasons for delays in test delivery results are classified into the following five categories:

1. Due to lack of responsibility.

2. Shortage of strain gauges accessories.

3. Staff limitations.

4. Poor understanding (technical difficulties).

5. Jig availability. 
The MTS has conducted a total of 664 tests between January 2003 to September 2007, with an average annual growth of 4.22 per cent between 2003 and 2006. This data is presented in Table 1. The reasons for late delivery in the specific year are illustrated in Figures 4 and 5.

Table 1: Test statistics from January 2003 to September 2007

\begin{tabular}{|c|c|c|c|c|c|}
\hline \multirow[b]{2}{*}{ Number of tests } & \multicolumn{5}{|l|}{ Year } \\
\hline & 2003 & 2004 & 2005 & 2006 & 2007 \\
\hline January & 14 & 12 & 12 & 8 & 8 \\
\hline February & 16 & 8 & 13 & 13 & 13 \\
\hline March & 10 & 9 & 11 & 9 & 9 \\
\hline April & 13 & 14 & 14 & 10 & 10 \\
\hline May & 11 & 12 & 9 & 14 & 14 \\
\hline June & 9 & 15 & 12 & 12 & 12 \\
\hline July & 7 & 11 & 10 & 16 & 16 \\
\hline August & 6 & 9 & 15 & 10 & 10 \\
\hline September & 12 & 12 & 11 & 15 & 15 \\
\hline October & 10 & 14 & 14 & 14 & \\
\hline November & 11 & 11 & 16 & 12 & \\
\hline December & 7 & 9 & 8 & 17 & \\
\hline Total tests per year & 126 & 136 & 145 & 150 & 107 \\
\hline Total tests delivered late & 31 & 28 & 31 & 45 & 82 \\
\hline Annual growth & & $7.35 \%$ & $6.21 \%$ & $3.33 \%$ & \\
\hline
\end{tabular}

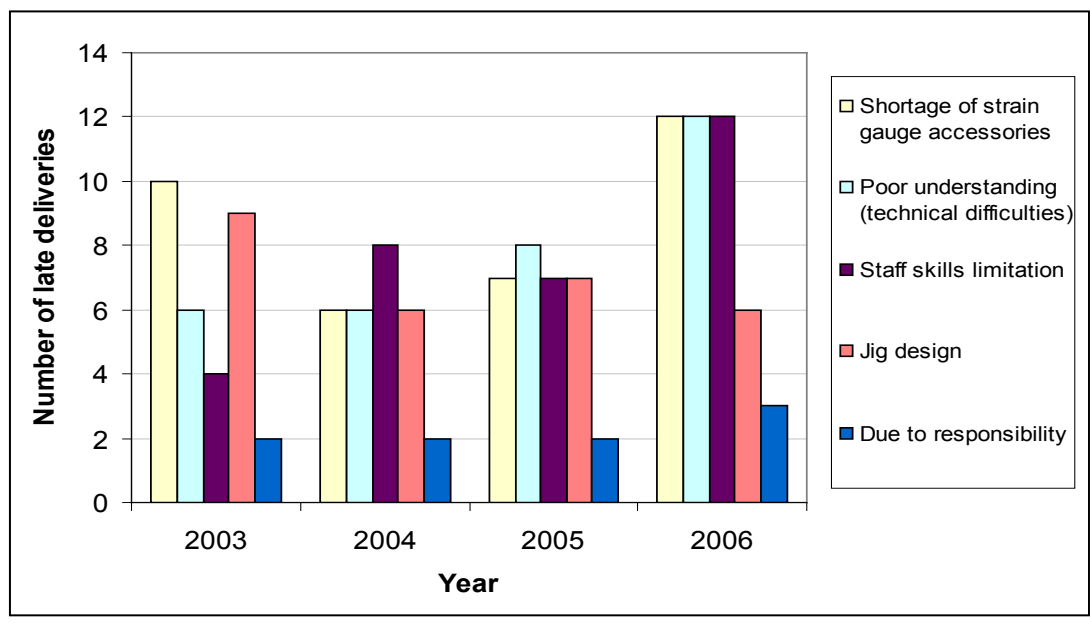

Figure 4: Reasons for late delivery 2003 - 2007 (see online version for colour image) 


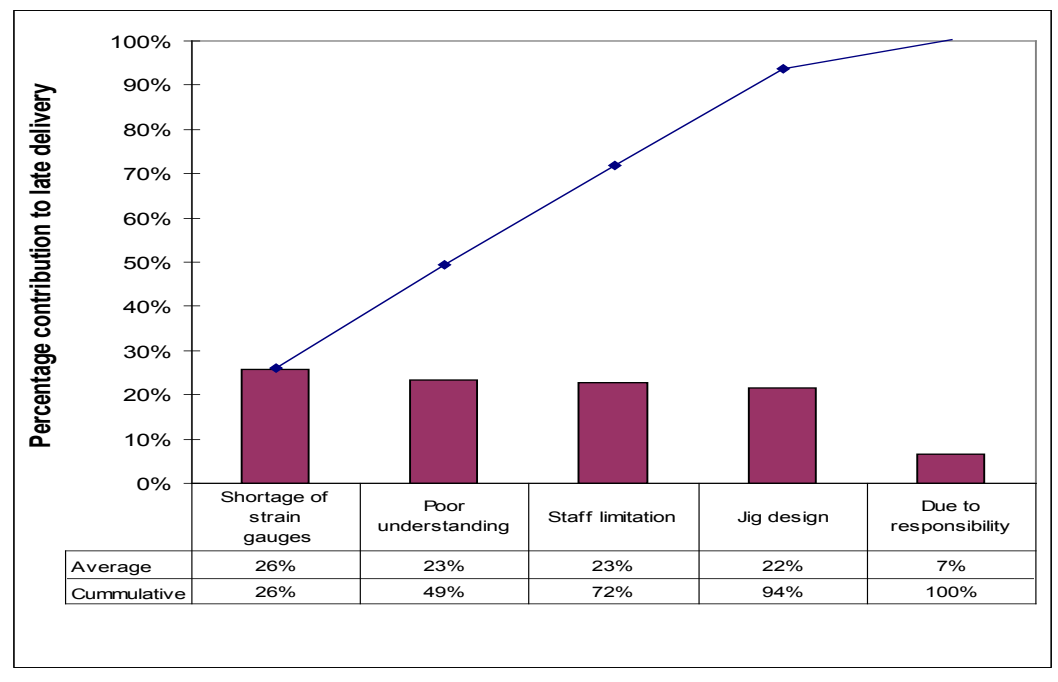

Figure 5: Average contribution of issues to late deliveries, $2003-2007$

It is evident from Figure 5 that the shortage of strain gauge accessories, such as glue and alcohol, is on average the largest contributor to late delivery. Due to the short shelf-life of these items, no stock is maintained in the workshop and thus re-ordering occurs on demand. The normal ordering process must be followed: three quotations must be obtained from external vendors, a purchase order prepared and approved by the operations manager, and then the materials can be collected. This ordering process can take up to three days.

The next largest contributor to late delivery is poor understanding of the test requirements. Although the technical supervisor is highly experienced within the MTS, at times he does not fully understand the requirements for the test initiated through him. As a result, the test is conducted incorrectly; delivery is further delayed when the client does not accept the results and the test must be redone. This category is a direct result of the nonadherence to the defined test request procedure.

Staff limitations, the third largest issue, refer to the key man dependencies experienced in the department, specifically:

- Lack of welding expertise: As the MTS relies on the availability of RSTDC resources for specialised welding, this often results in an unforeseen delay of the tests. Attempts to remedy the situation by the MTS by performing their own welding have often resulted in incorrect instrumentation, causing further delays at the end of the initial tests.

- MTS unable to collect specimen: Although the MTS commits on occasion to fetching the test specimens, this is often not possible due to lack of transport. A vehicle must be arranged with other departments, which can cause an undue delay in delivery.

- No knowledge of MTS: Although the engineering technician is responsible for the configuration of MTS for testing, only the technical supervisor has received training on the system and can assist with any hitches.

Delays in jig design are usually due to the following reasons:

- Jig search: As no records are maintained on the jigs in storage within the MTS, it can often take up to two days to conduct a search to confirm the availability of jigs believed to be in storage. Often, jigs cannot be found and the client is then requested to design or supply the jig.

- Jig manufacture: Lack of machine shop capacity can delay the commencement of jig manufacturing for up to two weeks. 
- Jig materials shortage: Jig manufacturing materials such as nuts and bolts are not catalogued or stored in any methodical manner; they therefore take a long time to find. When it is established that the materials are not available, the same ordering process is followed as previously described, with the associated three-day delay.

The last issue of lesser consequence is the lack of responsibility within the facility, where employees do not fulfil the tasks assigned to them, with no acceptable reason.

A comparison of the number of tests conducted between January and September 2006 and the same period in 2007 shows that very little growth has occurred in the MTS recently. In addition, the division is experiencing the lowest rate of delivery for the first nine months of 2007, suggesting that the problems are increasing substantially. From Figure 6, it is clear that the division has moved from achieving an average of 70.0 per cent on-time deliveries, to 23.4 per cent in less than a year.

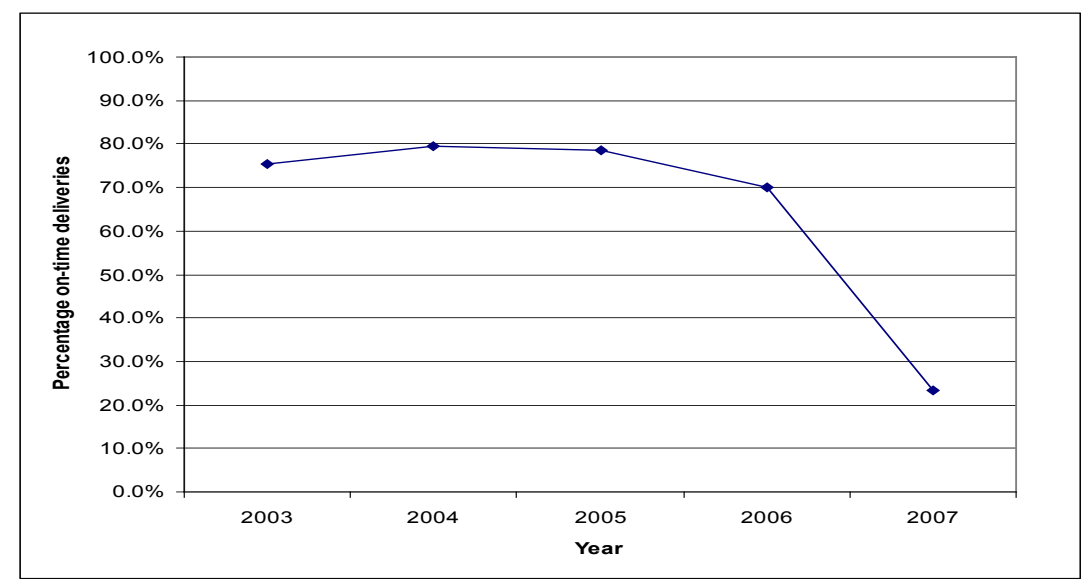

Figure 6: Yearly comparison of on-time deliveries

PROBLEM ANALYSIS

\subsection{SWOT analysis}

The SWOT analysis can be summarised as follows:

- MTS is well recognised and a favoured service provider within TFR and has a large potential for growth: The MTS workshop has a good reputation within TFRD and with external clients. The workshop is well recognised for the excellent work performed and charges very low rates, which saves TFRD a lot of capital. However, the marketing strategies employed by MTS within the TFR group are poor. The company should be getting a larger number of internal clients who may currently not be aware of MTS, although this is potentially threatened by the late deliveries.

- There is a significant skills shortage within the MTS: The operations manager and engineering technician are the only two employees who have been at MTS for many years and hence are the only two with the expertise. Although the MTS also has a fully accredited Material Testing System (MTS) in place, the technical supervisor is the only employee who has been trained to use the system;the engineering technician who operates it, however, has not been trained. The fact that the current team comprises of new staff members indicates that MTS has a dilemma with skills retention. This could become a major threat if no action is taken to retain and develop the necessary skills. 
Table 2: The strengths, weaknesses, opportunities, and threats surrounding the MTS workshop.

\begin{tabular}{|c|c|}
\hline STRENGTHS & WEAKNESSES \\
\hline $\begin{array}{l}\text { - } \quad \text { Reputation and recognition within } \\
\text { TFR and other external companies. } \\
\text { Great variety and number of tests } \\
\text { - } \quad \text { Highly experienced technical } \\
\text { supervisor and workshop assistant. } \\
\text { - Good facility equipment. } \\
\text { - } \quad \text { Location and easy accessibility. } \\
\text { - Sophisticated testing system in } \\
\text { place (MTS is a fully accredited } \\
\text { system). } \\
\text { Lower prices compared with } \\
\text { competitors. }\end{array}$ & 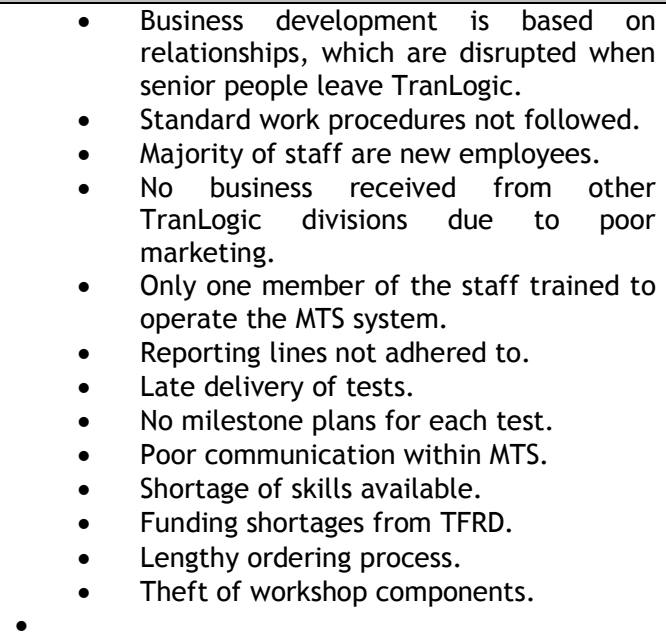 \\
\hline OPPORTUNITIES & THREATS \\
\hline $\begin{array}{l}\text { - Large pipeline of new business } \\
\text { available in TranLogic. } \\
\text { TranLogic purchasing new } \\
\text { locomotives and wagons - increasing } \\
\text { testing demand. }\end{array}$ & $\begin{array}{l}\text { - Unfair blame for failed components, } \\
\text { which were never submitted to MTS for } \\
\text { testing. } \\
\text { Another TFRD testing facility in } \\
\text { Hammanskraal, South Africa. } \\
\text { More attractive offers to skilled } \\
\text { engineers and technicians. }\end{array}$ \\
\hline
\end{tabular}

- Convoluted information flow within the department and overlap of responsibilities: Communication is a major problem; this is also evident in the information flow diagram depicted in Figure 7). The departmental structure in terms of communication links is poorly defined. Staff members are performing duties outside of their scope, which results in them misinterpreting the job requested by the client. Employees are not communicating via the correct channels due to a lack of standardised procedures. This non-adherence to procedure is not discouraged by the operations manager, who continues to approve the test requests submitted through the technical supervisor.

\subsection{Root cause analysis}

A review of the process flow diagram (Figure 2), the information flow diagram (Figure 3), and the observations made in the SWOT analysis has resulted in the identification of a number of root causes for the issue of late delivery within the MTS. The Ishikawa diagram used to conduct the root cause analysis is illustrated in Figure 7, and the issues are detailed below.

\section{Absence management}

- $\quad$ There are no set goals on what the MDS needs to achieve. This shows a lack of interest by the operations manager in what the MDS is doing. Without set goals, there is nothing that would motivate employees to perform better. In addition, the operations manager encourages the technical supervisor to disrespect the processes by continuing to take requests from clients instead of him directing them to the engineer who is charged with that responsibility. The problem with the technical supervisor taking orders from the clients is that in most cases, he does not capture all the information needed, which results in unnecessary delays (re-work as the client would have to be contacted again to clarify information). 


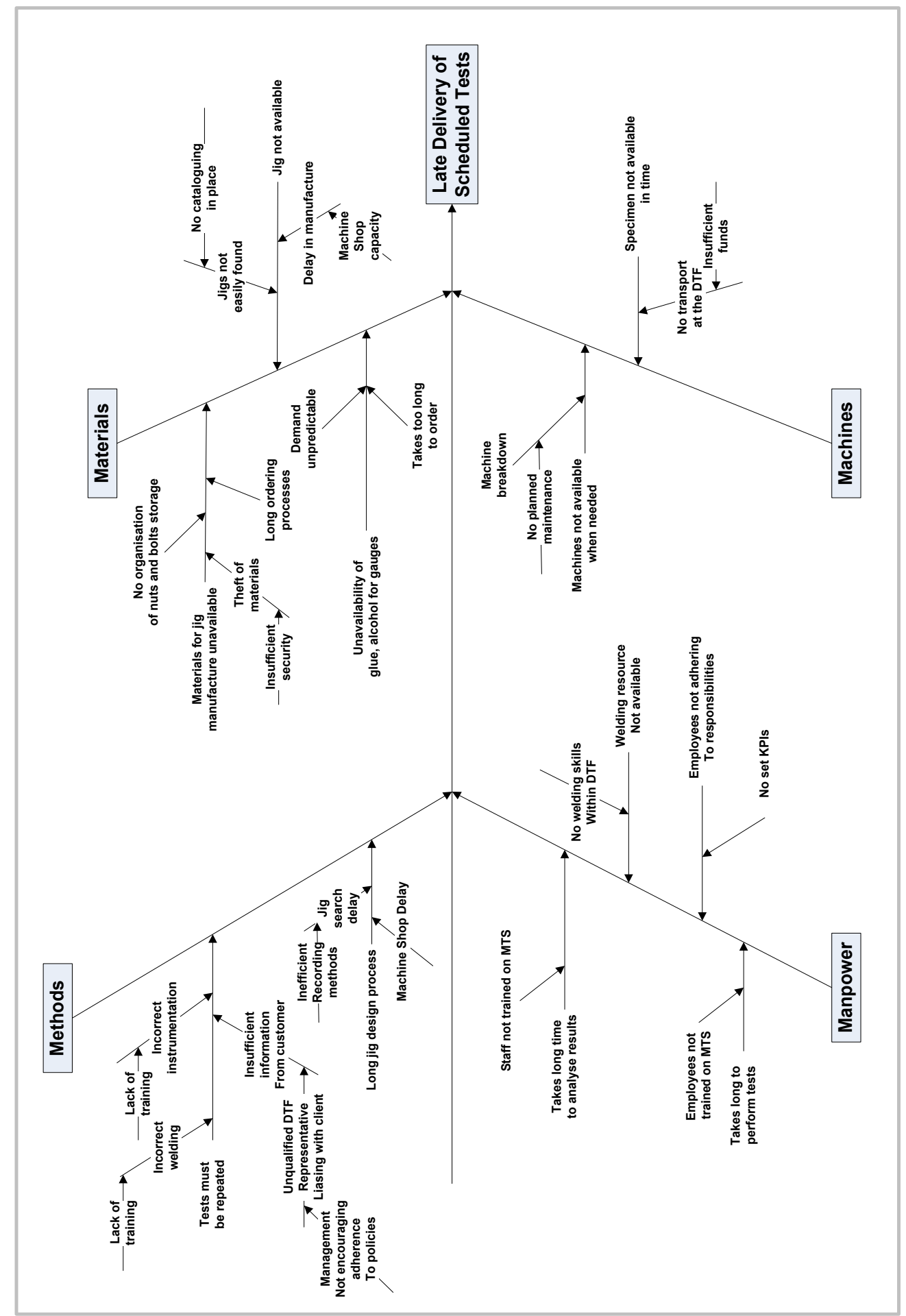

Figure 7: Root Cause Analysis of MTS Issues

- It is also worrying that orders from clients are received by different people at the MDS; i.e., there are three different entry points for orders from clients. Lack of 
standardisation is likely to continue to lead to confusion in the information exchanged between the different parties.

- There is no effective management of the MDS. The day-to-day running is assigned to an engineer who is not equipped to effectively manage the facility. The technical supervisor does not respect the authority of the engineer; for example, there have been instances when he leaves the facility during lunch-time without informing the engineer, and only comes back the following day. The operations manager does not have a management system that informs him of the performance of the MDS.

\section{Lack of training}

- The technical supervisor is the only person trained in the Material Testing Computer Aided Engineering System, which was purchased from the USA. All other employees are learning through trial and error. This situation is very risky because if the supervisor was to leave the company, it would pose challenges to the remaining staff.

- $\quad$ Furthermore, the lack of welding and instrumentation training within the MTS creates dependency on specific individuals, which worsens the situation. The evident lack of training could also be a reputational risk for the MTS.

\section{Ineffective storage methods}

- The process of searching for the correct jig for the test specimen is too laborious and time-consuming. The fact that the supervisor has to go to all storerooms to check if they have the correct size jig for the test specimen means that the facility does not have a system of recording and stacking jigs. Furthermore, if the correct jig is not available, a new jig is designed and manufactured, which is an additional cost that could be avoided.

- This issue also manifests itself in the storage of nuts and bolts used in jig manufacture, and could easily be avoided.

- Security at the MTS is too lax; for example, guards who are employed to guard the MTS property cannibalise the welding machines for copper, from time to time.

\section{Maintenance}

- Within the MTS, there is no maintenance policy in terms of the machinery. Machines are repaired as and when they break. Their machines are not always busy and it would be advisable for the MTS to adopt a planned maintenance programme.

\section{SOLUTIONS AND RECOMMENDATIONS}

- More active management

- The operations manager should, together with his employees, formulate key performance indicators (KPIs) for the MDS. Once these KPIs are formulated, he/she should set targets that the MTS should attain on an ongoing basis. Periodically, the operations manager should evaluate the MDS performance against set targets. This will help him/her to correct deviations when they occur.

- Based on the set KPIs, the MDS should produce a monthly report to the operations manager. These reports should reveal whether the MDS is operating in a manner agreed to between himself/herself and the MDS.

- Each position should have a job profile that clearly defines the position's responsibility and accountability. The reporting matrix should be clear to every employee; i.e., each employee should know who their superiors are and where to go if they need help in terms of their work and any human resources-related issue that may arise. Employees should be held accountable for their actions and any blatant disrespect for authority should be corrected/punished.

- $\quad$ Standard operating procedures

- The MTS should clearly define standardised methods for clients to request work. Clients should also use only one entry point for submitting their requests. 
- The MTS should draw a service level agreement (SLA) with the machine shop detailing what is expected of the workshop once they receive an order to make a jig. Compliance to the SLA should guarantee more work from the MTS, whereas failure to deliver as expected would result in a loss of business.

- $\quad$ Multipurpose jigs

- In order to avoid delays related to jig manufacturing, the facility is encouraged to design a multipurpose jig that would be suitable for all test specimens, with minor modifications. A single jig for the same component type with different dimensions should be considered.

- Work area organisation

- The problem of mixed small materials such as bolts and nuts should be solved by installing clearly labelled shelves in the storeroom. Materials of the same make and type should be stored on one shelf. This will facilitate easy identification of materials when they are needed.

- The problem of taking a long time to find the required jig for a particular operation could be addressed if jigs are labelled and their storage area is recorded on a system that is easy to use and is accessible to all employees who are authorised to use jigs.

- It is crucial to assimilate a general quality management framework in order to enhance the storerooms' organisation in terms layout, safety flow and security. The MTS could consider adopting the 5S principles to establish procedure in terms of a work environment that is conducive in the promotion of efficiency and effectiveness. The $5 \mathrm{~S}$ idea alludes to the five Japanese standards of seiri, seiton, seison, seiketsu, and shitsuke; otherwise referred to as sort, set, shine, standardise, and sustain.

- Training of employees

- The other two technically literate employees (i.e., the engineer and the engineering technician) should be trained on the MTS to eliminate trial and error learning.

- In addition to employing a professional welder, the technical supervisor and the technician should be trained to perform the welding function.

- All technically literate employees should be trained on the techniques for attaching strain gauges to the test specimen.

- Improved security

- The MTS should introduce access control to their storerooms and the workshop. Vehicles and people leaving the premises should be searched.

They should install surveillance cameras in the storerooms, workshop, and any strategic positions in the yard.

\section{IMPLEMENTATION AND MEASUREMENT}

Although a number of interventions have been highlighted in the section above, it is important to highlight the 'quick wins' that are attainable immediately with the lowest cost of resources, time, and capital, given the current funding shortage. The implementation of the abovementioned changes by management is expected to result in a remarkable and easily visible change in the MTS's performance. Analysis of the KPIs by management is not expected to take more than two weeks and should immediately eradicate most issues related to a lack of responsibility and technical difficulties; this would eliminate up to 30 per cent of the issues, at a low cost.

Implementing proper storage methodologies, such as labelling and recording existing jigs, constructing labelled shelves for the different bolt sizes and nuts, and implementing the $5 \mathrm{~S}$ system is expected to also yield great benefits; it might even substantially decrease the jig availability issue. The cost of implementing proper storage methodologies, as well as implementing shelving, would equal the salaries of the technical supervisor and the workshop assistant. By immediately implementing just these two items, the MTS should see a market improvement in their processes, at a minimal cost. These items, coupled with the 
SLA with the machine shop, should also assist with more accurate estimations of delivery dates in the future.

\section{REFERENCES}

[1] Zhou, J-S., Gong, D., Sun, W-J. \& Ren, L-H. 2009 Influence of vertical elasticity of carbody of railway passenger vehicles on ride quality [J]. Journal of the China Railway Society, 2, pp. 008.

[2] Shainesh, G. \& Mathur, M. 2000. Service quality measurement: The case of railway freight services. Vikalpa, 25(3), pp. 15-22.

[3] West, A., Ramagge, F., West, J. \& Jones, H. 1973. The quality of railway carriage environments. Applied Ergonomics, 4(4), pp. 194-8.

[4] Hansen, W. \& Hintze, H. 2005. Ultrasonic testing of railway axles with the phased array technique-experience during operation. Insight-Non-Destructive Testing and Condition Monitoring, 47(6), pp. 358-60.

[5] Trinh, V.N., Tang, A.M., Cui, Y-J., Dupla, J-C., Canou, J., Calon, N., Lambert, L., Robinet, A. \& Schoen, 0. 2012. Mechanical characterisation of the fouled ballast in ancient railway track substructure by large-scale triaxial tests. Soils and Foundations, 52(3), pp. 511-23.

[6] Wetenkamp, H.R., Sidebottom, O.M. \& Schrader, H.J. 1950. Effect of Brake Shoe Action on Thermal Cracking and on Failure of Wrought Steel Railway Car Wheels.

[7] Pipinato, A., Molinari, M., Pellegrino, C., Bursi, O.S. \& Modena, C. 2011. Fatigue tests on riveted steel elements taken from a railway bridge. Structure and Infrastructure Engineering, 7(12), pp. 907-20.

[8] Berbeglia, G., Cordeau, J-F., Gribkovskaia, I. \& Laporte, G. 2007. Static pickup and delivery problems: A classification scheme and survey. Top, 15(1), pp. 1-31.

[9] Min, H. 1989. The multiple vehicle routing problem with simultaneous delivery and pick-up points. Transportation Research Part A: General, 23(5), pp. 377-86.

[10] Rosenkrantz, D.J., Stearns, R.E. \& Lewis, I.I.P.M. 1977. An analysis of several heuristics for the traveling salesman problem. SIAM Journal on Computing, 6(3), pp. 563-81.

[11] Liedtka, J.M \& Whitten, E. 1997. Enhancing care delivery through cross-disciplinary collaboration: A case study. Journal of Healthcare Management/American College of Healthcare Executives, 43(2), pp. 185-203.

[12] McDonald, D.A. \& Pape, J. 2002. Cost Recovery and the Crisis of Service Delivery in South Africa. London: Zed Books.

[13] Keast, R \& Brown, K. 2002. The government service delivery project: A case study of the push and pull of central government coordination. Public Management Review, 4(4), pp. 439-59.

[14] Ala-Risku, T. \& Kãrkkãinen, M. 2006. Material delivery problems in construction projects: A possible solution. International Journal of Production Economics, 104(1), pp. 19-29.

[15] Bertelsen, S. \& Nielsen, J. 1997. Just-in-time logistics in the supply of building materials. 1st International Conference on Construction Industry Development, Singapore: 1997, p. 9-11.

[16] Kãrkkãinen, M., Holmstram, J., Frãmling, K. \& Artto, K. 2003. Intelligent products: A step towards a more effective project delivery chain. Computers in Industry, 50(2), pp. 141-51.

[17] Dainty, A.R.J, Millett, S.J. \& Briscoe, G.H. 2001. New perspectives on construction supply chain integration. Supply Chain Management: An International Journal, 6(4), pp. 163-73.

[18] Anumba, C.J. \& Ruikar, K. 2002. Electronic commerce in construction trends and prospects. Automation in Construction, 11(3), pp. 265-75.

[19] Elliman, T. \& Orange, G. 2000. Electronic commerce to support construction design and supplychain management: A research note. International Journal of Physical Distribution \& Logistics Management, 30(3/4), pp. 345-60.

[20] Drira, A., Pierreval, H. \& Hajri-Gabouj, S. 2007. Facility layout problems: A survey. Annual Reviews in Control, 31(2), pp. 255-67.

[21] Kusiak, A. \& Heragu, S.S. 1987. The facility layout problem. European Journal of Operational Research, 29(3), pp. 229-51.

[22] Mak, K.L, Wong, Y.S. \& Chan, F.T.S. 1998. A genetic algorithm for facility layout problems. Computer Integrated Manufacturing Systems, 11(1), pp. 113-27.

[23] Baykasoglu, A., Dereli, T. \& Sabuncu, I. 2006. An ant colony algorithm for solving budget constrained and unconstrained dynamic facility layout problems. Omega, 34(4), pp. 385-96. 